\title{
Spore morphology of Onychium ipii Ching (Pteridoideae, Pteridaceae)
}

\author{
A. V. Vaganov' ${ }^{1}$ I. I. Gureyeva ${ }^{2}$, A. A. Kuznetsov², A. I. Shmakov¹, R. S. Romanets ${ }^{2}$ \\ ${ }^{1}$ South-Siberian Botanical Garden, Altai State University, prospect Lenina, 61, Barnaul, 656049, Russia \\ E-mail:vaganov_vav@mail.ru \\ ${ }^{2}$ Tomsk State University, prospect Lenina, 36, Tomsk, 634050, Russia. E-mail: gureyeva@yandex.ru
}

Key words: morphology of the spores, scanning electronic microscopy (SEM), Onychium ipii, Pteridaceae, Pteridoideae.

Summary. The ultrastructure of the spore surface of Onychium ipii Ching (Pteridoideae, Pteridaceae) was investigated by using of scanning electron microscopy. Spores of Onychium ipii are trilete, tetrahedral, with hemispherical distal side and convex proximal one. Equatorial diameter 42.4-48.1 $\mu \mathrm{m}$, polar axis 35.7-40.6 $\mu \mathrm{m}$. Distal and proximal sides are separated by an equatorial flange, which protrudes on 4.3-4.8 $\mu \mathrm{m}$ all around the spore. Tubercles of different size form the interrupt "laesura lips" situated on both sides of laesura arms. Proximal side of spore with three stright ridges 3.1-4.5 $\mu \mathrm{m}$ width arranged parallel to spore margins and formed triangle in outline. Fused tubercles on distal side form sinuous folds with a few small areolae. Spores of Onychium ipii in compare with spores of O. moupinense Ching (Figure 3, D-F; Tables 1-2) are larger; their equatorial flange is more prominent; laesura arms are narrower; "laesura lips" are interrupted; stright ridges on the proximal side of spores Onychium ipii are broader, than the same in $O$. moupinense spores; sinuate folds on the distal side of Onychium ipii spores are more frequent than the same in $O$. moupinense spores. Spores of Onychium ipii and O. moupinense have the differences in the character of spore ornamentation and form. These features are the addition argument for recognition of Onychium ipii and $O$. moupinense as separate species.

\section{Морфология спор Onychium ipii Ching (Pteridoideae, Pteridaceae)}

\author{
А. В. Ваганов ${ }^{1}$, И. И. Гуреева ${ }^{2}$, А. А. Кузнецов ${ }^{2}$, А. И. Шмаков ${ }^{1}$, Р. С. Романец ${ }^{2}$ \\ ${ }^{1}$ Южно-Сибирский ботанический сад, Алтайский государственный университет, пр. Ленина, 61, \\ г. Барнаул, 656049, Россия. E-mail: ssbgbot@mail.ru \\ ${ }^{2}$ Томский государственный университет, пр. Ленина, 36, г. Томск, 634050, Россия. E-mail: gureyeva@yandex.ru
}

\begin{abstract}
Ключевые слова: морфология спор, сканирующая электронная микроскопия (СЭМ), Onychium ipii, Pteridaceae, Pteridoideae.

Аннотация. Методом сканирующей электронной микроскопии проведено сравнительное исследование морфологии спор Onychium ipii Ching. Выявлены основные признаки, характерные для спор вида. Споры трехлучевые, тетраэдрические, в проксимально-полярном и дистально-полярном положениях треугольноокруглые, стороны споры слегка выпуклые. В экваториальном положении проксимальная сторона выпуклая, дистальная - полусферическая. Экваториальный диаметр 42,4-48,1 мкм, полярная ось 35,7-40,6 мкм. Проксимальная и дистальная стороны разделяются хорошо выраженной экваториальной складкой 4,3-4,8 мкм шир., с выемками в углах споры. Лучи лезуры прямые, с расположенными в ряд по обеим сторонам каждого луча дискретными бугорками разного размера. Дистальная сторона споры извилисто-складчатая, с редкими небольшими ареолами. Близ экваториальной складки бугорки и складки дистальной стороны сливаются в сплошную складку, располагающуюся вокруг споры параллельно экваториальной. Проксимальная сторона с тремя пря-
\end{abstract}


мыми складками, расположенными близ краев споры параллельно экваториальной складке. Отличительными признаками, свойственными O. ipii в сравнении с O. тоирinense Ching, являются: больший размер спор, более широкие лучи лезуры, прерывистые утолщения вдоль лучей лезуры, более широкие краевые складки на проксимальной стороне споры, извилисто-складчатая орнаментация дистальной стороны споры. Отличия в форме и орнаментации спор являются дополнительным аргументом в пользу признания самостоятельности Onychium ipii и $O$. moupinense.

The genus Onychium contains about 10 species occuring in the border of warm-temperate and tropical zones mostly in the Sikkim-Himalayan area and southwest China, in northeast Africa, eastward to India, China, and Japan; in Malesia eastward to New Guinea (Tryon, Lugardon, 1991; Zhang G.M. et al., 2013). According to the last classifications, the genus Onychium belongs to subfamily Pteridoideae C. Chr. ex Crabbe, Jermy et Mickel, family Pteridaceae E. D. M. Kirchn. (Smith et al., 2006; Christenhusz et al., 2011). Most of species grow in the mountains at an altitude of $3500 \mathrm{~m}$ above sea level (Ching et al., 1990). Phylogenetic analysis on the base of sequencing of the chloroplast $r b c \mathrm{~L}$ gene demonstrates that Onychium is closely related to Actiniopteris Link and Pteris L. (Zhang G. et. al., 2005; Dou et al., 2015; Zhang L. et. al., 2017). Relationship of Onychium and Actiniopteris was confirmed also by molecular-phylogenetic studies, based on analysis of three plastid gene $(r b c \mathrm{~L}$, $\operatorname{atp} \mathrm{B}$, and $\operatorname{atp} \mathrm{A}$ ) data set; the genus Onychium is a member of one of five main clades - pteridoid clade (Schuettpelz et al., 2007). Relationship between Onychium and Actiniopteris is confirmed also by similarity in spore morphology (Kuznetsov et al., 2009, 2013; Vaganov et al., 2012).

Onychium ipii Ching was described as the separate species in 1936 (Ching, 1936; figures Ching, 1937). This species occurs in southeast China (provinces Sichuan and Hubei) and is considered as local endemic. Most authors treat this taxon as a variation of $O$. moupinense Ching - O. moupinense Ching var. ipii (Ching) K. H. Shing (Ching et al., 1990), or do not recognize it at all (Zhang G. M. et al., 2013).

A. V. Vaganov described a new series Moupinenses A. Vaganov (Vaganov, Shmakov, 2012) on the base of the form and dissection of frond: frond blade is elongate-lanceolate to linear, 2-3-pinnately divided. Both $O$. ipii and $O$. moupinense were included in this new serie. O. ipii has the differences with $O$. moupinense in the form of frond and the form of scales in the base of the stipe (Figure 1,2).

Several molecular-phylogenetic studies were conducted in Pteridoideae subfamily (Zhang L. et. al., 2017) and the genus Onychium (Dou et al., 2015) in the last years. But it is not possible to indicate what the specimens were used in these studies. L. Zhang et al. (2017) indicated the number of specimen of O. moupinense var. ipii as "Zhang X. C., 2999 (PE), Chongqing, China", but the correct number is 2699 (not 2999). Specimen No. 2699 was used also for sequencing by P. Dou et al. (2015). In fact, No. 2699 indicates five herbarium specimens in Herbarium PE (Institute of Botany, Chinese Academy of Sciences, Beijing). These specimens were identified by X. C. Zhang as $O$. japonicum or $O$. japonicum var. ipii (?); they have the same collection number (No. 2699) and different barcode. But barcode of specimen which was used for sequencing was not indicated in the study of P. Dou et al. (2015). So, we cannot say, what specimen was used for molecularphylogenetic studies. One of the authors of this study, A. V. Vaganov, identified four of these six specimens No. 2699 (PE: 01385258; 01385256; 01385254; $01385255 ; 01385257$; 01385259$)$ as O. moupinense (PE: 01385254; 01385255; 01385257; 01385259), two of them was identified as O. ipii (PE: 01385258; 01385256).

Spores of some Onychium species were studied and described by B. K. Nayar and S. Devi (1967) (Onychium japonicum (Thunb.) Kunze, O. lucidum (D. Don.) Spreng., O. siliculosum (Desv.) C. Chr.), brief description and SEM-micrographs of spores of three Onychium species (O. contiguum (Wall.) C. Hope, O. siliculosum, O. divaricatum (Poir. in Lam.) Alston) are given by A. Tryon and B. Lugardon (1991), spores of 6 Onychium species (O. siliculosum, O. contiguum, O. japonicum, O. plumosum Ching, O. lucidum, O. moupinense) studied by using of scanning electronic microscope (SEM) were described by A. V. Vaganov et al. (2012). The most characteristic features for Onychium spores are the following: tetrahedral-globose shape, trilete aperture, prominent equatorial flange and coarse adjacent ridges, coarsely tuberculate or rugate proximal face, reticulate-tuberculate distal face; the outer layer with sparse granulate deposit (Tryon, Lugardon, 1991).

The aim of present work is the searching of features in spore ornamentation detectable with using of scanning electronic microscope for confirmation of the distinctness of $O$. ipii from O. moupinense. 


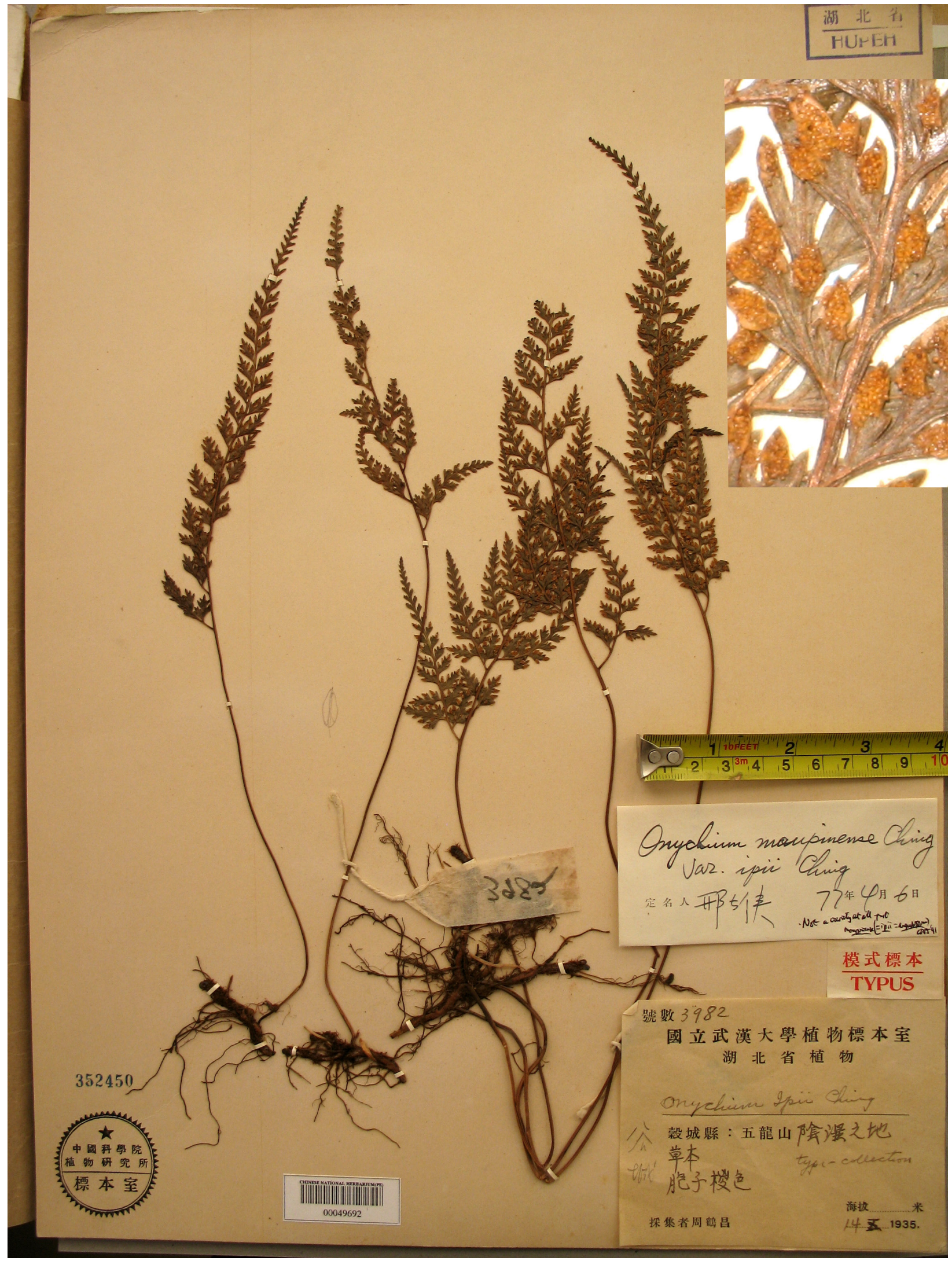

Fig. 1. The type specimen of Onychium ipii Ching (PE-00049692). 


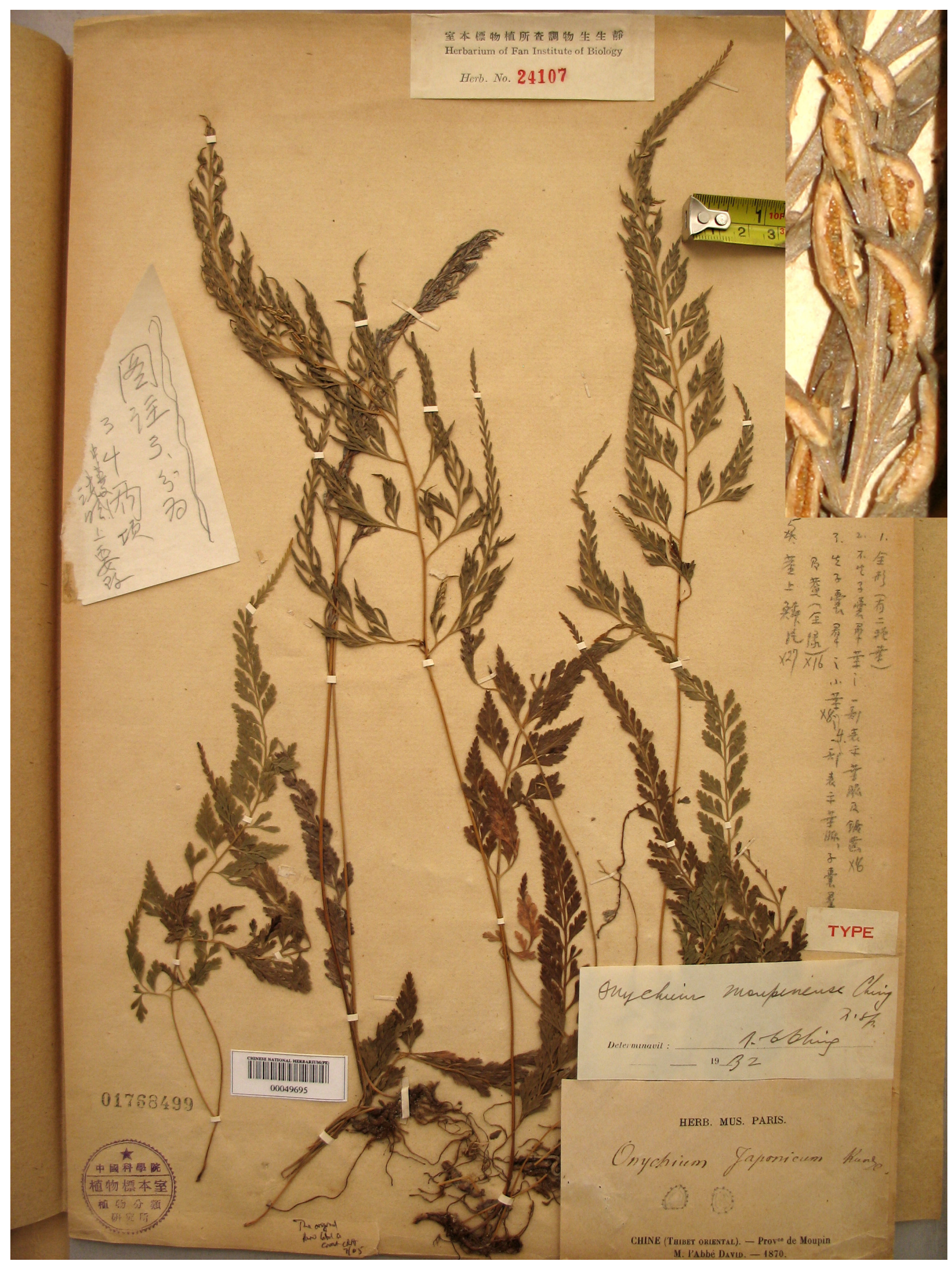

Fig. 2. The type specimen of Onichium moupinense Ching (PE-00049695). 

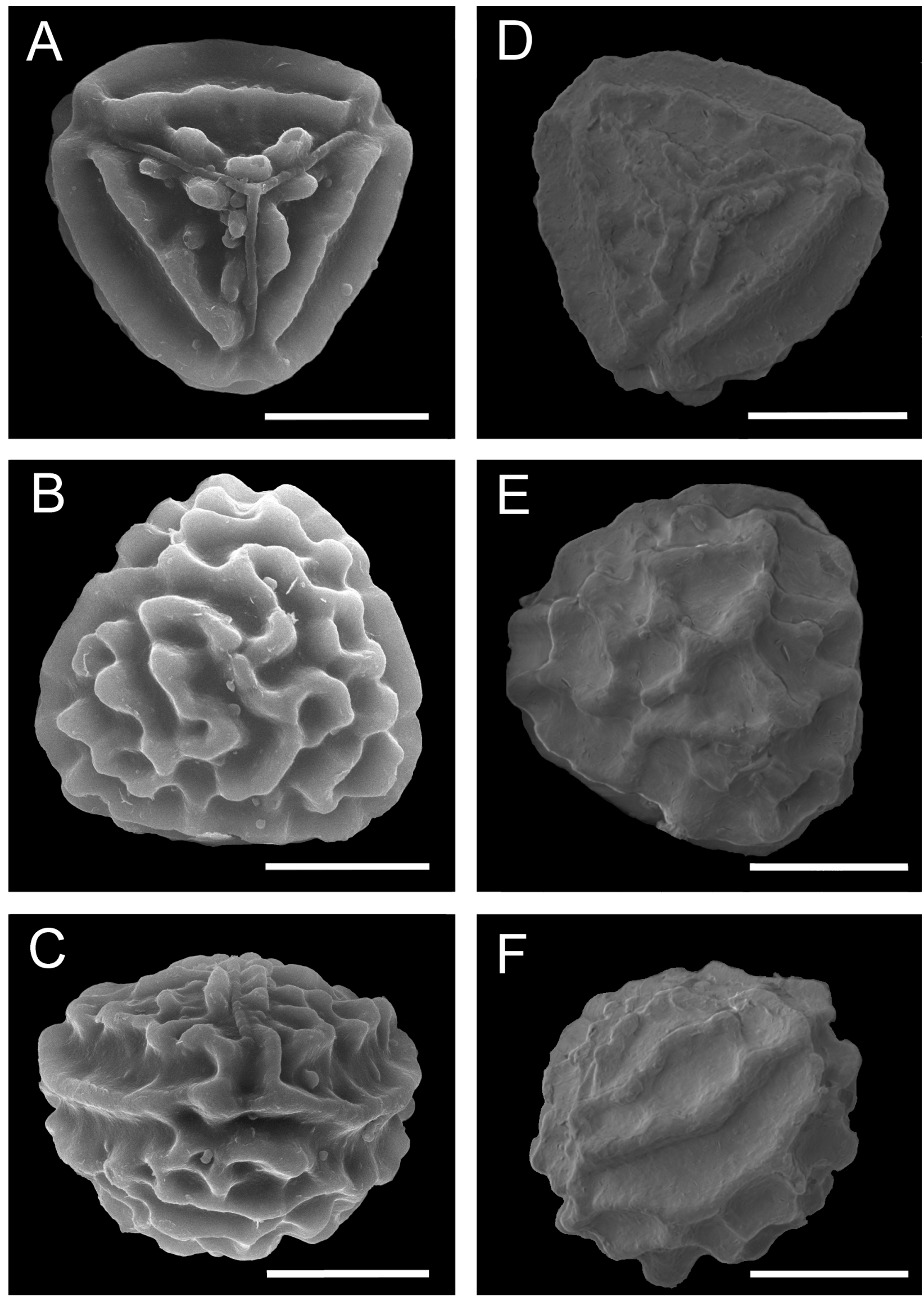

Fig. 3. SEM-micrographs of spores of Onichium ipii $(\mathrm{A}-\mathrm{C})$ and $O$. moupinense (D-F): A, D - proximal side of spores; B, E - distal side of spore; C, F - spores in equatorial position, proximal side at top, distal side from below, equatorial flange in the middle. Scale bars $-20 \mu \mathrm{m}$. Photos of O. moupinense from A. V. Vaganov et al. (2012) and A. A. Kuznetsov et al. (2013). 


\section{Matherials and methods}

The study includes spores of Onychium ipii collected in Hubei province of China. Spores were obtained from herbarium specimen stored in PE (Herbarium of Institute of Botany, Chinese Academy of Sciences, Beijing). Identification of specimen was conducted by author of this article A.V. Vaganov. Identification was made on the basis of morphological features of fronds. Only mature spores from adult fronds were used for SEM observations. Spores were mounted on SEM stubs using double-sided carbon adhesive tape and coated with gold in a "Quorum Q150R S" sputtercoater. Stubs were viewed and photographed with a scanning electronion microscope "Mini-SEM SNE$4500 \mathrm{M}$ " in the laboratory of structural and molecular analysis of plants (Tomsk State University, Tomsk, Russia). Spore surfaces were scanned in a high vacuum at voltage of 25 to $30 \mathrm{kV}$, through $400 \times$ to $14000 \times$ magnification.

The equatorial diameter, polar axis, length and width of laesura arms, ridges and folds were used as the main morphometrical characters. All measurements were made on SEM-micrographs of spores in distal, proximal and equatorial positions using the computer program "Image J". 25 measurements of each parameter were made. For terminology, we primarily followed B. P. Nayar and S. Devi $(1966,1967)$, they described spores observed under light microscope; A. Tryon and B. Lugardon (1991), they described spores of some Onichium species observed in SEM. SEMmicrographs of Onychium moupinense Ching were published earlier (Vaganov et al., 2012; Kuznetsov et al., 2013).

Investigated specimen: "Shennongjia Forest District $\left(31^{\circ} 30^{\prime} \mathrm{N}, 110^{\circ} 30^{\prime} \mathrm{E}\right)$ : vicinity of Houshanping on the $\mathrm{S}$ side of the Hou River. Elevation $800-1050 \mathrm{~m}$. In thin soul at the base of boulders and ledges. 24. 01. 1981. Sino-American Botanical Expedition to Westren Hubei Province Peoples Repubic of China, No. 1599. 21 September 1980" (PE-01385245).

\section{Results and conclusion}

Onychium ipii (Figure 2, A-C; Tables 1-2). Spores trilete, tetrahedral, in distal-polar and proximal-polar positions triangular with broadly rounded corners and convex sides. The equatorial diameter of spore $44.3(42.4-48.1) \mu \mathrm{m}$, polar axis $37.7(35.7-40.6) \mu \mathrm{m}$. Distal side of spore in equatorial position hemispherical, proximal side is convex. Two sides are separated by an equatorial flange, which protrudes in $4.5(4.3-4.8) \mu \mathrm{m}$ all around the spore as seen in polar position; equatorial flange 3.2 (2.9-3.6) $\mu \mathrm{m}$ thick in equatorial position. Equatorial flange concave in the corners as seen in proximal-polar position. Laesura arms stright, 15.8 (13.6-19.8) $\mu \mathrm{m}$ long and $1.1(0.7-1.4) \mu \mathrm{m}$ wide, elevated above the spore surface, with a row of regularly arranged along both sides of each laesura arm particularly fused tubercles. So, tubercles

Table 1

Comporative morphometrical characters of the spores of Onychium ipii and $O$. moupinense, mean $(\min -\max )$

\begin{tabular}{|l|c|c|}
\hline \multicolumn{1}{|c|}{ Feature } & O. ipii & O. moupinense \\
\hline Equatorial diameter, $\mu \mathrm{m}$ & $44.3(42.4-48.1)$ & $37.3(31.4-41.9)$ \\
\hline Polar axis, $\mu \mathrm{m}$ & $37.7(35.7-40.6)$ & $37.1(37.4-37.87)$ \\
\hline Equatorial flange in polar position (width), $\mu \mathrm{m}$ & $4.5(4.3-4.8)$ & $3.9(2.8-5.03)$ \\
\hline Laesura arms (width), $\mu \mathrm{m}$ & $1.1(0.7-1.4)$ & $1.6(1.3-2.1)$ \\
\hline Laesura lips (width), $\mu \mathrm{m}$ & $2.4(1.8-2.9)$ & $3.4(3.4-4.0)$ \\
\hline Ridges on the proximal side of spore (width), $\mu \mathrm{m}$ & $3.6(3.1-4.5)$ & $2.5(1.9-3.1)$ \\
\hline
\end{tabular}

Table 2

Comparative characteristics of spore ornamentation of Onychium ipii and O. moupinense

\begin{tabular}{|l|c|c|}
\hline \multicolumn{1}{|c|}{ Feature } & O. ipii & O. moupinense \\
\hline Equatorial flange & prominent and broad & prominent and broad \\
\hline Laesura arms & stright, elevated above the spore surface & stright, elevated above the spore surface \\
\hline Laesura lips & $\begin{array}{c}\text { interrupted, formed from fused } \\
\text { tubercles }\end{array}$ & uninterrupted, roller-like \\
\hline Ridges on the proximal side & stright & stright \\
\hline Distal side & sinuate-folded with a few small areolae & $\begin{array}{c}\text { with fused elongate tubercles, formed } \\
\text { large areolae }\end{array}$ \\
\hline
\end{tabular}


of different size form the interrupt "laesura lips" situated on both sides of laesura arms. Proximal side of spore with three stright ridges $3.6(3.1-4.5)$ $\mu \mathrm{m}$ wide, arranged parallel to spore margins and forming triangle in outline. Fused tubercles on distal side form sinuous folds 2.8 (1.9-3.5) $\mu \mathrm{m}$ wide, with a few small areolae. Fused tubercles and folds form a regular row parallel to the equatorial flange. Surface is nearly smooth with rare round excrescences $0.2-$ $0.6 \mu \mathrm{m}$ in diam.

In general, spores of Onychium ipii and O. moupinense have the differences in the character of spore ornamentation and shape. Spores of Onychium ipii, in compare with spores of O. moupinense (Figure 3, D-F; Tables 1-2) are larger, their equatorial flange is more prominent and broader; laesura arms are narrower, "laesura lips" are interrupted; stright ridges on the proximal side of Onychium ipii spores are broader, than the same in O. moupinense spores; sinuate folds on the distal side of Onychium ipii spores are more frequent then the same in $O$. moupinense spores. Differentiation in spore morphology is the addition argument for recognition of Onychium ipii and O. moupinense as separate species. Confusion in identification of these species can lead to incorrect results particularly in molecular-phylogenetic studies.

\section{Acknowledgements}

The research was partially supported by Russian Foundation for Basic Research (grant No. 16-04-00513-A) and Tomsk State University competitiveness improvement program. The authors are grateful to curators of the Herbarium PE (Herbarium of Institute of Botany, Chinese Academy of Sciences, Beijing).

\section{REFERENCES}

Ching R.-Ch. 1936. Fan Memorial Institute of Biology. New a Little Known Ferns. Lingnan Science Journal 15 (2): $1-282 \mathrm{pp}$.

Ching R.-Ch. 1937. Onychium. In: Icones Filicum Sinicarum, Fascicle. Peiping, China, 161-164.

Ching R. Sh. K., Shing K., Lin Y., Wu Sh., Wu S. 1990. Onychium Kaulf. In: Flora Reipublicae Popularis Sinicae. Pekini, 3(1): 103-112.

Christenhusz M. J. M., Zhang X.-C., Schneider H. 2011. A linear sequence of extant families and genera of lycophytes and ferns. Phytotaxa 19: 7-54.

Dou P., Yang W.-L., Zhao R.-R., Zhang G.-M. 2015. Phylogenetic analysis of Onychium based on five chloroplast DNA sequences. Bull. Bot. Res. 35: 665-671.

Kuznetsov A. A., Gureyeva I. I., Vaganov A. V., Shmakov A. I. 2009. Taxonomic revision of the genus Anopteris (Prantl) Diels (Cryptogrammaceae). Turczaninowia 12, 1: 5-16 [In Russian]. (Кузнецов А. А., Гуреева И. И., Ваганов А. В., Шмаков А. И. Морфологический анализ спор видов рода Actiniopteris Link (Cryptogrammaceae) // Turczaninowia, 2009. Т. 12, вып. 1. - С. 5-16).

Kuznetsov A. A., Vaganov A. V., Gureyeva I. I., Shmakov A. I. 2013. Spore morphology of the Cryptogrammaceae ferns and allied genera. Barnaul, Altai State University Publ., 64 pp. [In Russian and English]. (Кузнецов А. А., Ваганов А. В., Гуреева И. И., Шмаков А. И. Морфология спор папоротников семейства Cryptogrammaceae и близких к нему родов. Барнаул: Изд-во Алт. ун-та, 2013. 64 с.

Nayar B. K., Devi S. 1966. Spore morphology of the Pteridaceae. I. The Pteridoid ferns. Grana palinologica 6(3): $368-593$.

Nayar B. K., Devi S. 1967. Spore morphology of the Pteridaceae. II. The Gymnogrammoid ferns. Grana palinologica 7(2-3): 368-593.

Schuettpelz E., Schneider H., Huiet L., Windham M. D., Pryer K. M. 2007. A molecular phylogeny of the fern family Pteridaceae: assessing overall relationships and the affinities of previously unsampled genera. Molecular Phylogenetics and Evolution 44: 1172-1185.

Smith A. R., Pryer K. M., Schuettpelz E., Korall P., Schneider H., Wolf P. G. 2006. A classification for extant ferns. Taxon 3, 55: 705-731.

Tryon A. F., Lugardon B. 1991. Spores of Pteridophyta: Surface, Wall Structure, Diversity Based on Electron Microscope Studies. New York inc., Springer Ferlag. 648 pp.

Vaganov A. V., Shmakov A. I. 2012. A system of the genus Onychium Kaulf. (Cryptogrammaceae). Turczaninowia 15, 1: 25-27 [In Russian]. (Ваганов А. В., Шмаков А. И. Система рода Onychium Kaulf. (Cryptogrammaceae) // Turczaninowia, 2012. Т. 15, вып. 1. С. 25-27).

Vaganov A. V., Shmakov A. I., Kuznetsov A. A., Gureyeva I. I., Babeshina L. G. 2012. Morphological analysis of spores of species of the genus Onychium Kaulf. (Cryptogrammaceae). Turczaninowia 15, 3: 59-67 [In Russian]. (Ваганов А. В., Шмаков А. И., Кузнецов А. А., Гуреева И. И., Бабешина Л. Г. Морфологический анализ спор видов Onychium Kaulf. (Cryptogrammaceae) // Turczaninowia, 2012. T. 15, вып. 3. С. 59-67). 
Zhang G. M., Liao W. B., Ding M. Y., Lin Y. X., Wu Z. H., Zhang X. C., Dong S. Y., Prado J., Gilbert M. G., Yatskievych G., Ranker T. A., Hooper E. A., Alverson E. R., Metzgar J. S., Funston A. M., Masuyama S., Kato M. 2013. Pteridaceae. In: Flora of China. Vol. 2-3 (Pteridophytes). Eds Z. Y. Wu, P. H. Raven, D. Y. Hong. Beijing, Science Press; St. Louis, Missouri Botanical Garden Press, 169-256 pp.

Zhang G., Zhang X., Chen Z. 2005. Phylogeny of cryptogrammoid ferns and related taxa based on rbcL sequences. Nordic Journal of Botany 23: 485-493.

Zhang L., Zhou X-M., Thi Lu N., Zhang L-B. 2017. Phylogeny of the fern subfamily Pteridoideae (Pteridaceae; Pteridophyta), with the description of a new genus: Gastoniella. Molecular Phylogenetics and Evolution 109: 59-72. DOI: http://dx.doi.org/10.1016/j.ympev.2016.12.037 